\title{
PENERAPAN TEKNOLOGI SABO SEBAGAI PENAHAN LAJU SEDIMENTASI PADA MUARA DANAU LIMBOTO
}

\section{THE IMPLEMENTATION OF SABO TECHNOLOGY IN LIMBOTO'S ESTUARY SEDIMENTATION FLOW RETAINMENT}

\section{Ardian Alfianto $^{1)^{*}}$ Shandy Ceciliaa ${ }^{2)}$ Banata Wachid Ridwan ${ }^{1)}$ Chitra Widyasani Surya Putri ${ }^{3)}$}

\author{
1)Balai Teknik Sabo, Jl. Sabo No. 1 Sopalan, Maguwoharjo, Depok, Sleman, Yogyakarta 55282 \\ 2) Tokyo Institute of Technology, 4259 Nagatsutacho, Midori Ward, Yokohama, Kanagawa 226-0026 \\ 3) Balai Pelaksana Penyediaan Perumahan Jawa III, Jl. Laksda Adisucipto No.165, Demangan Baru, \\ Caturtunggal, Kec. Depok, Kabupaten Sleman \\ *Coressponding author: art.diean@gmail.com
}

Diterima: 27 Mei 2019; Direvisi: 30 Mei 2019; Disetujui: 12 Juni 2020

\begin{abstract}
Lake siltation due to erosion and sedimentation in Limboto Lake has happened since 1932. Based on 2017 analysis, lake contriction reached 4,000 (88,81 hectares annually). So, Limboto is predicted to go extinct in 2031. Since 2017, sabo dam implementation includes a series of effort called 'Limboto Lake Revitalization' to retain sedimentation flow. This study aims to review and to compare existing data with latest primary data collected. Measurement of sedimentation potential volume is done using software WaTEM/SEDEM, sabo design, and sabo plan. Overall, sabo plan designed by Sulawesi II River Basin Office is sufficient to accommodate potential of erotion and sedimentation flow in Limboto, despite the hypothesis that sabo dam amount is lacking and structure is positioned unfit with sabo design standard. The review shows that based on accommodating capacity, it is not necessary to add structure in upstream river. On the other hand, based distance between structures, each river requires at least 1 additional structure. This study advises an additional of capacity surge to 1.111 .537 cubic meters. Batulayar section has the biggest capacity of 193.662 cubic meters per year, while the smallest is located in Tabongo1 with a capacity of 11.031 cubic meters per year. Updating and scheduled sabo dam review are required.
\end{abstract}

Keywords: Sedimentation, erosion, Limboto Lake, sabo dam, WaTEM/SEDEM

\begin{abstract}
ABSTRAK
Pendangkalan akibat erosi dan sedimentasi di Danau Limboto terjadi sejak 1932. Berdasarkan analisis tahun 2017, penyempitan danau mencapai 4.000 hektar (88,81 hektar per tahun). Sehingga, diprediksi Danau Limboto akan hilang pada tahun 2031. Sejak 2017, penerapan teknologi sabo termasuk serangkaian upaya 'Revitalisasi Danau Limboto' untuk menahan laju sedimentasi. Kajian ini meninjau ulang kemampuan Sabo Dam dalam menahan laju sedimentasi dengan analisis data kasus banjir riil, potensial, serta membandingkan data yang ada dengan data primer termutakhir. Perhitungan potensi sedimentasi dihitung dengan perangkat lunak WaTEM/SEDEM, rumus perencanaan sabo, dan sabo plan. Secara umum, perencanaan sabo oleh Balai Wilayah Sungai Sulawesi II cukup menanggulangi potensi erosi dan sedimentasi di Kawasan Danau Limboto, menepis hipotesis awal kajian, yaitu jumlah Sabo Dam kurang serta letak bangunan belum sesuai dengan kaidah perencanaan sabo. Hasil peninjauan ulang Sabo Dam, berdasarkan parameter kapasitas tampung, penambahan bangunan di sungai hulu danau tidak diperlukan. Di sisi lain, berdasarkan jarak antar bangunan Sabo Dam, masing-masing sungai memerlukan minimum 1 bangunan tambahan. Usulan penambahan kapasitas tampung mencapai $1.111 .537 \mathrm{~m}^{3}$. Sub-DAS Batulayar memiliki kapasitas tampung terbesar $193.662 \mathrm{~m}^{3}$ per tahun, sedangkan terkecil yaitu Tabongo1 memiliki Sabo Dam dengan kapasitas mencapai $11.031 \mathrm{~m}^{3}$ per tahun. Perlu adanya pembaruan dan peninjauan Sabo Dam terjadwal.
\end{abstract}

Kata Kunci: Sedimentasi, erosi, Danau Limboto, Sabo Dam, WaTEM/SEDEM 


\section{PENDAHULUAN}

Danau Limboto adalah aset sumberdaya alam Provinsi Gorontalo, selain berperan sebagai muara 23 (dua puluh tiga) sungai, danau ini juga berperan dalam mengendalikan banjir, penyedia air baku, habitat flora dan fauna, sarana transportasi, rekreasi dan olahraga (Kementerian Lingkungan Hidup dan Kehutanan, 2014). Kementerian Pekerjaan Umum dan Perumahan Rakyat, melalui Publikasi PUPR (2017), menyatakan Danau Limboto sebagai salah satu danau kritis akibat pendangkalan dan harus segera dilakukan revitalisasi.

Erosi dan sedimentasi yang mengakibatkan pendangkalan dasar danau utamanya disebabkan oleh usaha budidaya dan kegiatan penebangan pohon di hutan yang berada di hulu DAS Limboto, yang seharusnya bertindak sebagai daerah tangkapan air. Terhitung sejak 1932 - 2006, penyempitan danau mencapai 4.000 hektar $(88,81$ hektar per tahun). Berdasarkan angka ini, maka dapat diprediksi 25 (dua puluh lima) tahun kemudian Danau Limboto akan hilang (Kementerian Pekerjaan Umum dan Perumahan Rakyat, 2017).

Faktor utama penyebab pendangkalan Danau Limboto yaitu erosi karena maraknya penebangan pohon secara illegal di kawasan hutan lindung yang memperparah sedimentasi, akibat berkembangnya usaha pertanian dan perkebunan di area konservasi tanah (Kementerian Lingkungan Hidup, 2015). Perencanaan sabo merupakan tindakan aksi yang sesuai untuk mengurangi sedimentasi yang bertanggungjawab langsung terhadap pendangkalan danau.

Sebagai salah satu kegiatan dalam rangkaian 'Revitalisasi Danau Limboto' yang dilaksanakan pada 2017, teknologi sabo sebagai bentuk penerapan perencanaan sabo yang komprehensif diharapkan dapat menahan laju sedimentasi dari sungai-sungai yang bermuara ke Danau Limboto. Identifikasi lokasi, volume erosi, dan sedimen yang berpotensi menjadi sedimentasi Danau Limboto dibutuhkan sebagai dasar perencanaan bangunan penahan sedimen (Sabo Dam) yang tepat.

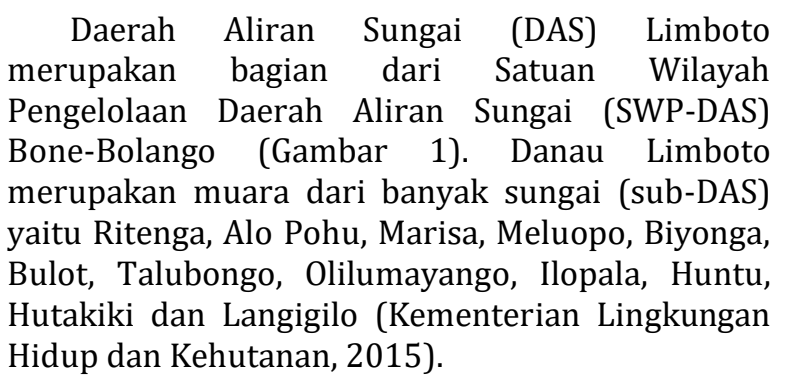

DAS Limboto mencapai 89.038 ha dengan SubDAS Batulayar, Sub-DAS Molamahu dan Sub-DAS
Alo sebagai 3 (tiga) terluas dari 20 (dua puluh) bagian DAS yang bermuara ke badan air dengan luas masing-masing mencapai $15.028 \mathrm{ha}, 12.766$ ha dan 10.968 ha.

Namun, review sabo plan belum dilaksanakan oleh Balai Besar Wilayah Sungai Sulawesi II sehingga kajian ini bertujuan untuk melakukan peninjauan ulang terhadap perencanaan sabo yang sudah dilakukan pada hulu danau. Kajian ini juga bermaksud melakukan identifikasi jumlah Sabo Dam pada sungai dan perhitungan potensi volume erosi serta sedimen yang mungkin menyebabkan pendangkalan di Danau Limboto.

Teknologi sabo merupakan salah satu bangunan yang efektif dalam mengendalikan sedimen. Bangunan ini digunakan untuk menahan sedimen di bagian hulu (area produksi), mengendalikan fluktuasi dasar sungai di area transportasi dan menampung sedimen di area deposisi (bagian hilir). Sabo Dam juga dapat mengalirkan sisa sedimen ke hilir, misalnya sungai utama dan laut (Takahashi, 2007). Teknologi Sabo pertama kali diperkenalkan pada tahun 1970 di daerah gunungapi untuk penanganan aliran lahar hujan, seperti di kawasan Gunungapi Merapi, Kelud, Semeru, Agung, dan Galunggung (Puslitbang SDA, 2014).

Dalam perencanaannya, Teknologi Sabo tidak hanya memperhitungkan kemampuan bangunan untuk dapat menahan gaya-gaya yang bekerja pada bangunan sesuai SNI 2851:2015. Namun juga kemampuan bangunan mengendalikan atau menampung volume material sedimen, seperti volume tampungan mati (dead storage) dan volume sedimen terkendali (control volume).

Tahun 2006 telah disusun Master Plan Pengelolaan Danau Limboto, hasil Kerjasama PSL Universitas Negeri Gorontalo, Balitbangpedalda Provinsi Gorontalo, dengan Kementerian Negara Lingkungan Hidup Republik Indonesia (Rifkah S. Akibu, 2017). Untuk mengurangi pendangkalan waduk oleh sedimentasi yang berasal dari hulu, BWS Sulawesi II membangun 3 buah penangkap sedimen atau check dam di hulu DAS Danau Limboto (Kementerian Pekerjaan Umum dan Perumahan Rakyat, 2019).

Perencanaan Sabo Dam dengan pendekatan kuantitatif dilaksanakan berdasarkan dua sumber data pokok, yaitu jumlah potensi sedimen/debris dan jumlah angkutan sedimen/debris. Perencanaan sabo berdasarkan jumlah potensi sedimen/debris, memberikan risiko jumlah dan dimensi bangunan sabo yang diperlukan besar apabila potensi sedimen/debris juga besar. Setiap 5 tahun sekali perencanaan sabo harus dievaluasi untuk mengetahui apakah perlu penambahan atau pengurangan jumlah ataupun kapasitasnya 
sehubungan adanya perubahan pasokan sedimen. Konsep ini dapat diterapkan apabila potensi sedimen/debris dapat diestimasi secara akurat. Serta penambangan tidak dapat dilaksanakan karena material yang tidak bisa dimanfaatkan dan tidak ada lokasi dumping area. Sementara perencanaan sabo berdasarkan jumlah angkutan sedimen/debris, pada konsep ini memberikan keuntungan jumlah sabo yang diperlukan relatif kecil. Namun, pemeliharaan kapasitas bangunan sabo/kantong sedimen perlu dilakukan berkala. Konsep ini dapat diterapkan jika kondisi penambangan material sedimen mudah dilaksanakan, serta material nya dapat dimanfaatkan sebagai bahan bangunan atau keperluan lain. Oleh sebab itu, strategi penanganan sedimen dapat dilakukan dengan menahan dan mengurangi angkutan sedimen pada DAS hulu dan sungai inlet, dengan pembuatan Sabo Dam di hulu sungai.

\section{METODOLOGI}

Penelitian ini menggunakan metodologi studi kasus, dengan pendekatan metode penelitian kuantitatif. Penelitian dilakukan dengan cara studi kasus tentang menahan sedimentasi di danau limboto dengan penerapan teknologi sabo. Analisis perencanaan sabo, dilakukan dengan cara mereview dan menghitung ulang untuk kebutuhan bangunan sabo di sungai yang merupakan hulu dari danau Limboto. Review disini dilakukan terhadap jumlah Sabo Dam, ukuran, serta kapasitas tampungnya.

\section{Pelaksanaan peninjauan ulang (review) perencanaan sabo}

Tahapan kajian dimulai dengan estimasi jumlah sedimen sasaran yang terdiri 7 (tujuh) tahapan. Tahapan berupa: 1) penghitungan sedimen tidak stabil yang terdiri dari potensi sedimen dari erosi lereng, sedimen akibat tebing sungai yang runtuh, sedimen akibat erosi tebing sungai dan sedimen yang sudah ada di sepanjang dasar sungai, 2) penghitungan sedimen tidak stabil yang belum terlihat saat ini, dan berpotensi terlihat di masa mendatang hasil erupsi di daerah vulkanik, 3) penghitungan nilai total sedimen tidak stabil, 4) penghitungan sedimen terangkut, 5) pemilihan nilai terkecil antara sedimen tidak stabil dan sedimen terangkut, 6) penetapan sedimen yang diperbolehkan ada di alur sungai bagian hilir Sabo Dam, dan 7) penghitungan selisih antara potensi sedimen dengan sedimen rencana. Selanjutnya kesesuaian lahan dinilai dengan membandingkan antara penggunaan lahan dengan zonasi angkutan sedimen

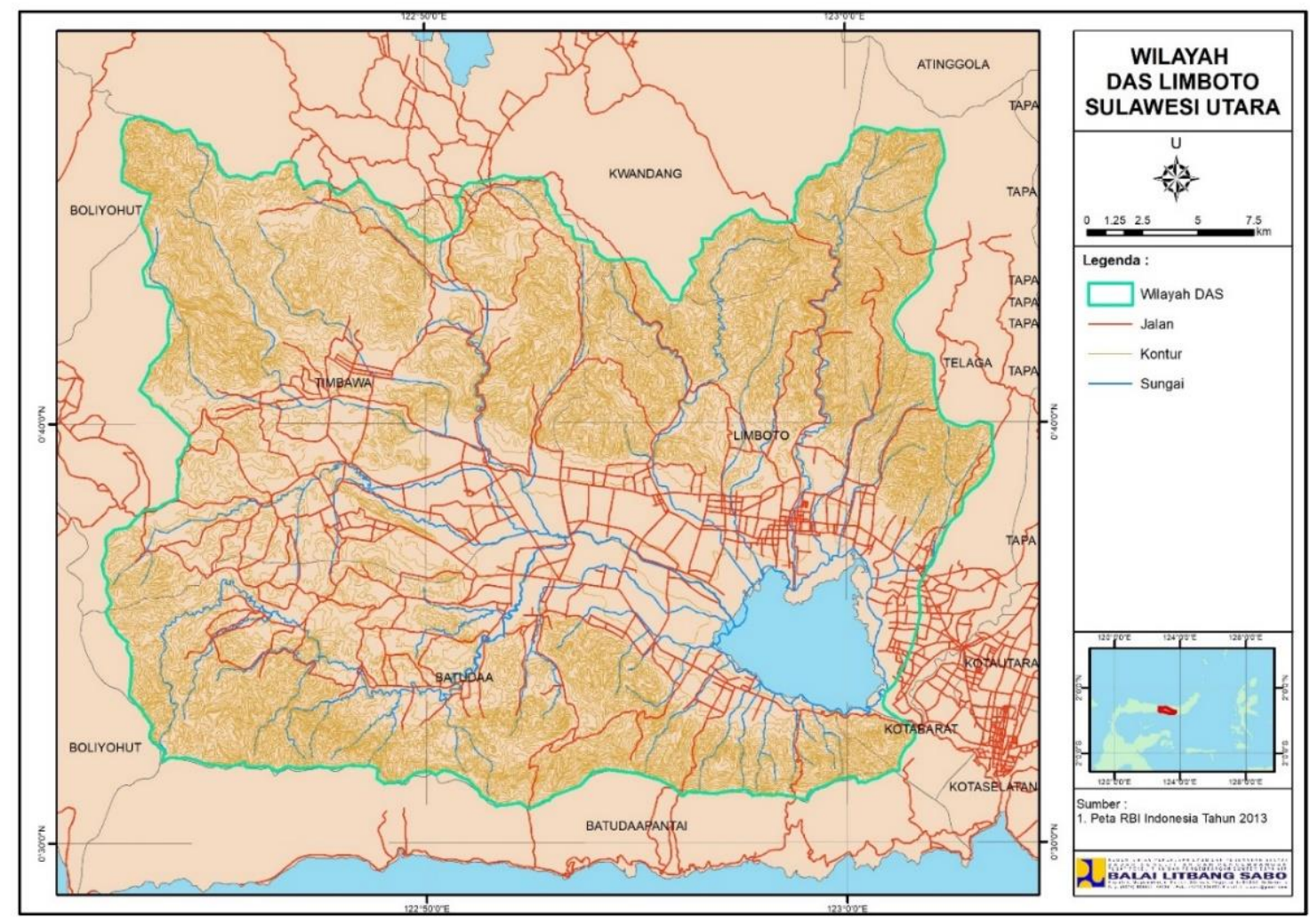

Sumber: Analisis, 2017

Gambar 1 Daerah Wilayah Sungai Danau Limboto 
Tabel 1 Data sekunder terkait sungai-sungai di hulu Danau Limboto

\begin{tabular}{|c|c|c|}
\hline Uraian & Jumlah & Tahun \\
\hline \multicolumn{3}{|l|}{ A. Peta-Peta di DAS Limboto } \\
\hline Peta Topografi DAS Limboto & 1 & 2008 \\
\hline Peta Penggunaan Lahan DAS Limboto & 1 & 2008 \\
\hline Peta Tanah DAS Limboto & 1 & 2008 \\
\hline Peta Geomorfologi DAS Limboto & 1 & 2008 \\
\hline Peta Erodibilitas DAS Limboto & 1 & 2008 \\
\hline $\begin{array}{l}\text { Peta Topografi dan Bathimetri Danau } \\
\text { Limboto }\end{array}$ & 1 & 2008 \\
\hline Peta Geologi & 1 & 2010 \\
\hline $\begin{array}{l}\text { Peta Master Plan Mitigasi Banjir } \\
\text { Cekungan Limboto-Bone-Bolango }\end{array}$ & 1 & 2010 \\
\hline $\begin{array}{l}\text { Peta Rekomendasi Batas Daerah } \\
\text { Sempadan Danau }\end{array}$ & 1 & 2010 \\
\hline \multicolumn{3}{|c|}{ B. Data Teknis Perencanaan Sabo DAS Limboto } \\
\hline Sungai Alo & 3 & 2009 \\
\hline Sungai Ambara & 1 & 2009 \\
\hline Sungai Bolangga & 2 & 2009 \\
\hline Sungai Marisa & 1 & 2009 \\
\hline Sungai Meluopo & 1 & 2009 \\
\hline Sungai Molalahu & 2 & 2009 \\
\hline Sungai Pohu & 2 & 2009 \\
\hline Sungai Tololudu & 1 & 2009 \\
\hline \multicolumn{3}{|l|}{ C. Data Hasil Pengukuran (Topografi) } \\
\hline Bathimetri dan Debit Danau Limboto & 1 & 2009 \\
\hline $\begin{array}{l}\text { Laporan Survei dan Pengolahan Data } \\
\text { Topografi dan Bathimetri }\end{array}$ & 1 & 2009 \\
\hline Deskripsi BM dan CP & 36 & 2009 \\
\hline Tabel Pengukuran & 9 & 2009 \\
\hline \multicolumn{3}{|l|}{ D. Bahan Paparan/Presentasi } \\
\hline Banjir Provinsi 2 & 1 & 2011 \\
\hline Danau Limboto & 1 & 2011 \\
\hline Gubernur Bahan & 1 & 2008 \\
\hline $\begin{array}{l}\text { Isu Strategis Pengelolaan SDA Provinsi } \\
\text { Gorontalo }\end{array}$ & 1 & 2011 \\
\hline Konservasi Danau Limboto & 1 & 2013 \\
\hline $\begin{array}{l}\text { E. Laporan Perencanaan Konservasi } \\
\text { Lingkungan Perairan Danau Limboto }\end{array}$ & 1 & 2008 \\
\hline $\begin{array}{l}\text { F. Laporan Perencanaan Bangunan } \\
\text { Pengendali Sedimen DAS Limboto }\end{array}$ & 1 & 2009 \\
\hline $\begin{array}{l}\text { G. Laporan Detail Desain Bangunan } \\
\text { Penangkap Sedimen Danau Limboto }\end{array}$ & 1 & 2010 \\
\hline $\begin{array}{l}\text { H. Laporan Perencanaan Sabuk Hijau } \\
\text { Danau Limboto }\end{array}$ & 1 & 2010 \\
\hline I. Laporan Model Fisik Danau Limboto & 1 & 2015 \\
\hline
\end{tabular}

Sumber: Penulis, 2017
Kapasitas tampungan Sabo Dam dihitung berdasarkan volume sedimen tertampung (Vds), volume sedimen yang dikendalikan (Vc) dan volume sedimen tertahan (Vd). Setelah kapasitas tampungan dihitung, zona angkutan sedimen sungai diidentifikasi berdasarkan zonasi angkutan sedimen. Dengan membandingkan volume sedimen sasaran dengan kapasitas tampung Sabo Dam, kesesuaian jarak antar bangunan, dan letak bangunan pada zonasi angkutan sedimen, maka dihasilkan Model Sistem Perencanaan Sabo di hulu Danau Limboto. Hal ini dituangkan dalam peta dan matriks tipe prioritas penanggulangan banjir lahar.

Data sekunder (Tabel 1) yang digunakan dalam kajian diperoleh dari Balai Besar Wilayah Sungai Sulawesi II. Peninjauan ulang perencanaan sabo dilakukan pada 20 (dua puluh) sungai yang mencakup review kapasitas tampung Sabo Dam, dan estimasi jumlah sedimen berlebih. Hasil keluaran berupa peta tematik terkait kondisi fisik dan non-fisik DAS Limboto.

\section{Perhitungan laju sedimentasi dengan WaTEM/SEDEM}

WaTEM/SEDEM merupakan model erosi berbasis distribusi spasial yang dikembangkan oleh Physical and Regional Geography Research Group, bertujuan untuk mensimulasikan kondisi lahan sehingga mengetahui besarnya erosi dan hasil sedimen di DAS serta lokasi terjadinya prosesproses tersebut. WaTEM/SEDEM biasanya diaplikasikan untuk daerah tangkapan luas yang mencakup beragam kondisi lingkungan, termasuk daerah berbukit, beragam variasi ekosistem di Italia, daerah hutan di Afrika Selatan dan perkebunan Belgium (Alatorre dkk, 2010). Model ini secara umum memprediksi erosi berbasis model RUSLE (Revised Universal Soil Loss Equaition) untuk memperhitungkan kehilangan tanah di lahan, perhitungan pola limpasan dengan mempertimbangkan algoritma aliran dan batas area pengaliran, pengolahan lahan, dan keberadaan infrastruktur jalan (Van Rompaey dkk, 2005). Sedimen dihitung berdasarkan jalur aliran menuju sungai terdekat dengan mempertimbangkan kapasitas transportasi sedimen sebanding dengan potensi erosi alur.

$A=R \times K \times L s \times C \times P$

Harian

$R=2.467 P d^{2} \times 0.02727 P d+0.725$.

Bulanan

$R=6.199 \times P \times 1.21 \times H H-0.47($ Pmaks $) 0.53$

Tahunan

$R=237.4+2.61$ 
Metode Wischmeier dan Smith/Departemen Pertanian Amerika Serikat (1978)

$100 K=2.1 \times M 1.14(10-4)(12-a)+3.25(b-$

2) $+2.5(c-3)$

Metode Poesen dalam Notebaert dkk (2006)

$K=0.0035+0.0038 \exp ((\log D g+1.519) /$

$0.7584) 2$

$\operatorname{Dg}(\mathrm{mm})=e \sum f 1 \cdot \ln [(d i+d i+i) 0.5]$

Metode Wischmeier dan Smith/Departemen Pertanian Amerika Serikat (1978)

$S(i, j)=65.41 \sin 2 \theta i, j+4.56 \sin \theta i, j+0.065(8)$

Dengan: A adalah Kehilangan Tanah/Erosi (Ton/Ha/Tahun), R adalah Erosivitas Hujan (MJ.mm/Ha.Tahun), $\mathrm{K}$ adalah Erodibilitas Tanah (Ton/HJ.mm), LS adalah Faktor Kemiringan Dan Panjang Lereng, L adalah Panjang Lereng, S adalah Faktor S, $\theta$ adalah Sudut Kemiringan Lereng, C adalah Faktor Tanaman, $\mathrm{P}$ adalah Faktor Pengolahan Lahan, $\mathrm{P}_{\mathrm{d}}$ adalah Curah Hujan Harian (mm), P adalah Curah Hujan Bulanan/Tahunan (mm), Pmaks adalah Curah Hujan Harian Maksimum (mm), HH adalah Jumlah Hari Hujan, M adalah Harkat Tekstur Tanah, a adalah Persentase Kandungan Organik, b adalah Harkat Struktur, c adalah Harkat Permeabilitas Tanah, Dg adalah Besar Butir Tanah Rata-Rata, d adalah Besar Butir Tanah. Metode Perkiraan Berdasarkan Kementerian Lingkungan Hidup dan Kehutanan (Kironoto dalam Tunas, 2008)

Tabel 2 Erodibilitas tanah menurut jenis

\begin{tabular}{l|c}
\hline \multicolumn{1}{c|}{ Jenis Tanah } & $\begin{array}{c}\text { Erodibilitas } \\
\text { Tanah }\end{array}$ \\
\hline $\begin{array}{l}\text { Latosol Coklat Kemerahan dan } \\
\text { Litosol }\end{array}$ & 0,43 \\
\hline $\begin{array}{l}\text { Latosol Kuning Kemerahan dan } \\
\text { Litosol }\end{array}$ & 0,36 \\
\hline Komplek Mediteran dan Litosol & 0,46 \\
\hline Latosol Kuning Kemerahan & 0,56 \\
\hline Grumusol & 0,20 \\
\hline Aluvial & 0,47 \\
\hline Regosol & 0,4 \\
\hline
\end{tabular}

Sumber: Kementerian Lingkungan Hidup dan Kehutanan, 2006
Perhitungan hasil sedimen dimulai dengan menghitung sedimen transport (Notebaert dkk, 2006).

$T C=K t c \times R \times K(L s-4.12 \times S g \times 0.8)$

Dengan: TC adalah Transport Sedimen, Ktc adalah Koefisien Transport, Sg adalah Kemiringan Lereng Setempat, R adalah Erosivitas Hujan (MJ.mm/Ha.Tahun), K adalah Erodibilitas Tanah (Ton/HJ.mm), Ls adalah Faktor Kemiringan Dan Panjang Lereng.

\section{Penerapan teknologi sabo (perencanaan sabo)}

Hassan (2018) menjabarkan seluruh proses penerapan teknologi sabo yang terdiri dari 10 (sepuluh) langkah, yang bisa kita lihat pada Gambar 2. Perencanaan Sabo Dam dapat dilaksanakan berdasarkan 2 (dua) konsep/pertimbangan.

Perencanaan Sabo Dam berbasis jumlah potensi sedimen dilaksanakan dengan evaluasi seluruh rencana minimal setiap 5 (lima) tahun atau 10 tahun untuk menentukan kebutuhan penambahan atau pengurangan kapasitas dan jumlah Sabo Dam. Konsep ini dapat digunakan jika potensi sedimen dapat diperkirakan dengan akurat. Sementara perencanaan berbasis transport debris dapat diterapkan jika material sedimen dapat digunakan untuk material bangunan dan tujuan lain, atau lahan untuk pembangunan Sabo Dam terbatas (Hassan, 2018).

Udiana (2011) menjabarkan berbagai macam fasilitas bangunan sabo yang dapat diterapkan untuk mengendalikan sedimen, antara lain: 1) dam pengendali atau dikenal dengan Sabo Dam yang salah satunya berfungsi untuk mengatur arah aliran, menstabilkan kaki bukit untuk mencegah longsor serta menahan dan mengendalikan sedimen yang akan mengalir ke hilir dengan mengurangi debit puncak; 2) tanggul untuk mencegah aliran debris menuju tempat aman dan mencegah limpasan debris; 3) kantong pasir untuk menampung dan membatasi penyebaran aliran debsris; 4) saluran pengatur kanal untuk meluruskan alur; 5) tanggul terbuka untuk mengendalikan arah aliran; dan 6) perlindungan tebing untuk melindungi tebing dari ancaman erosi. 


\begin{tabular}{|l|}
\hline Rencana Dasar \\
\hline -Memperkirakan jumlah produksi sedimen \\
-Membuat rencana manajemen sedimen dengan \\
- Proses evaluasi ekonomi untuk mengatur kemungkinan \\
keuntungan terkait investasi \\
- Memeriksa kecukupan biaya investasi, dengan \\
mempertimbangkan biaya untuk proyek \\
-Penentuan prioritas setelah menyusun rencana \\
tahunan yang didasarkan pada 4 langkah diatas \\
Merancang Bangunan Sabo Dam \\
•Penentuan ukuran dan detail struktur Sabo Dam \\
• Survei rinci dan geologi berdasarkan rencana \\
pengaturan bangunan dan survei Sabo Dam untuk \\
konfirmasi alternatif ukuran dan detil \\
-Membuat implementasi rancangan bangunan yang \\
telah ditentukan sebelumnya (tahap sebelumnya) \\
Pembangunan Sabo Dam \\
• Pelaksanaan rancangan implementasi pembangunan \\
Sabo Dam \\
kapasitas ekspektasi
\end{tabular}

Sumber: Hassan, 2018

Gambar 2 Langkah penerapan teknologi sabo

\section{HASIL DAN PEMBAHASAN}

\section{Sisa tampungan sedimen Sabo Dam di DAS Limboto}

Kalibrasi hasil pemodelan erosi yang dilakukan dengan WaTEM/SEDEM, adalah dengan membandingkan hasil pemodelan (Sediment Production) dengan data pengukuran sedimentasi pada danau. Sedimentasi danau di DAS Limboto diselesaikan dengan pengurangan sedimentasi di hulu melalui penerapan perencanaan sabo. Data pengukuran sedimentasi pada danau diperoleh berdasarkan hasil pengukuran yang dilakukan oleh JICA pada tahun 2002. Berdasarkan hasil tersebut didapatkan rata-rata volume sedimentasi dari danau Limboto sebesar 1X106 sampai dengan 2X106 m3/tahun (BWS Sulawesi II). Kalibrasi hasil dilakukan berdasarkan data sekunder JICA dan BWSS II.

Berdasarkan hasil analisis dan pengukuran didapatkan nilai potensi produksi sedimen Kawasan Danau Limboto sebesar 1.500.000 m3/tahun. Produksi sedimen yang mencapai $1.472 .832 \mathrm{~m} 3$, dengan produksi deposisi mencapai 694.563 m3; sedangkan ekspor sedimen mencapai
$778.268 \mathrm{~m} 3$ dan ekspor sungai sebesar 388.735 m3.

Hasil perhitungan kapasitas tampung bangunan di masing-masing sungai dapat kita lihat pada

Tabel 3. Volume tampung rencana Sabo Dam, didapatkan dari penjumlahan volume tampungan mati serta volume kontrol Sabo Dam. Sisa tampungan Sabo Dam di tiap sungai didapatkan dari volume tampung rencana dikurangi volume sedimen rencana pada tiap sungai. Berdasar kapasitas tampungan Sabo Dam pada Sungai Alo serta Alo1 pada Tabel 2, terlihat bahwa tampungan cukup mampu mengendalikan volume sedimen sasaran/berlebih yang ada. Sungai Alo dapat menampung sebesar $118.404 \mathrm{~m} 3$, sedangkan total volume sedimen berdasarkan banjir rancangan 50 tahunan didapatkan sebesar 115.204 m3. Sabo Dam Sungai Alo1 dapat menampung sedimen sebesar $120.495 \mathrm{~m} 3$, dengan potensi sedimen sebesar $120.272 \mathrm{~m} 3$. Jadi secara keseluruhan masih mampu mengisi tampungan secara maksimal, serta masih tersedia untuk sisa tampungan sebesar 2,7\% serta 1,8\% tampungan. 
Tabel 3 Kapasitas tampungan Sabo Dam di Kawasan Danau Limboto

\begin{tabular}{|c|c|c|c|c|}
\hline No & Lokasi Rencana Sabo Dam & $\begin{array}{l}\text { Volume Tampung Rencana } \\
\text { Sabo Dam }(V d+V c)\end{array}$ & Volume (m³/Thn) & $\begin{array}{c}\text { Sisa Tampungan } \\
\left(\mathrm{m}^{3} / \text { Thn }\right)\end{array}$ \\
\hline 1 & Alo & 118.404 & 115.204 & 3.200 \\
\hline 2 & Alo1 & 120.495 & 120.273 & 222 \\
\hline 3 & Batulayar & 197.366 & 193.662 & 3.704 \\
\hline 4 & Biyonga bulota & 125.914 & 123.095 & 2.818 \\
\hline 5 & Biyonga bulota1 & 26.291 & 25.895 & 396 \\
\hline 6 & Marisa & 58.266 & 57.075 & 1.192 \\
\hline 7 & Molamahu & 75.192 & 73.058 & 2.133 \\
\hline 8 & Molamahu1 & 40.464 & 39.585 & 879 \\
\hline 9 & Payunga & 26.987 & 26.746 & 241 \\
\hline 10 & Pilolalenga & 33.124 & 32.306 & 819 \\
\hline 11 & Pilolalenga1 & 22.558 & 21.841 & 717 \\
\hline 12 & Pone & 40.932 & 40.254 & 679 \\
\hline 13 & Pone1 & 27.519 & 27.306 & 214 \\
\hline 14 & Pulubala & 54.803 & 53.445 & 1.358 \\
\hline 15 & Pulubala1 & 18.023 & 17.741 & 282 \\
\hline 16 & Pulubala2 & 31.913 & 31.267 & 646 \\
\hline 17 & Tabongo & 20.441 & 20.151 & 290 \\
\hline 18 & Tabongo1 & 11.195 & 11.031 & 164 \\
\hline 19 & Talumelito & 32.533 & 32.247 & 286 \\
\hline 20 & Tuladengi & 29.157 & 28.908 & 249 \\
\hline
\end{tabular}

Sumber: Analisis, 2017

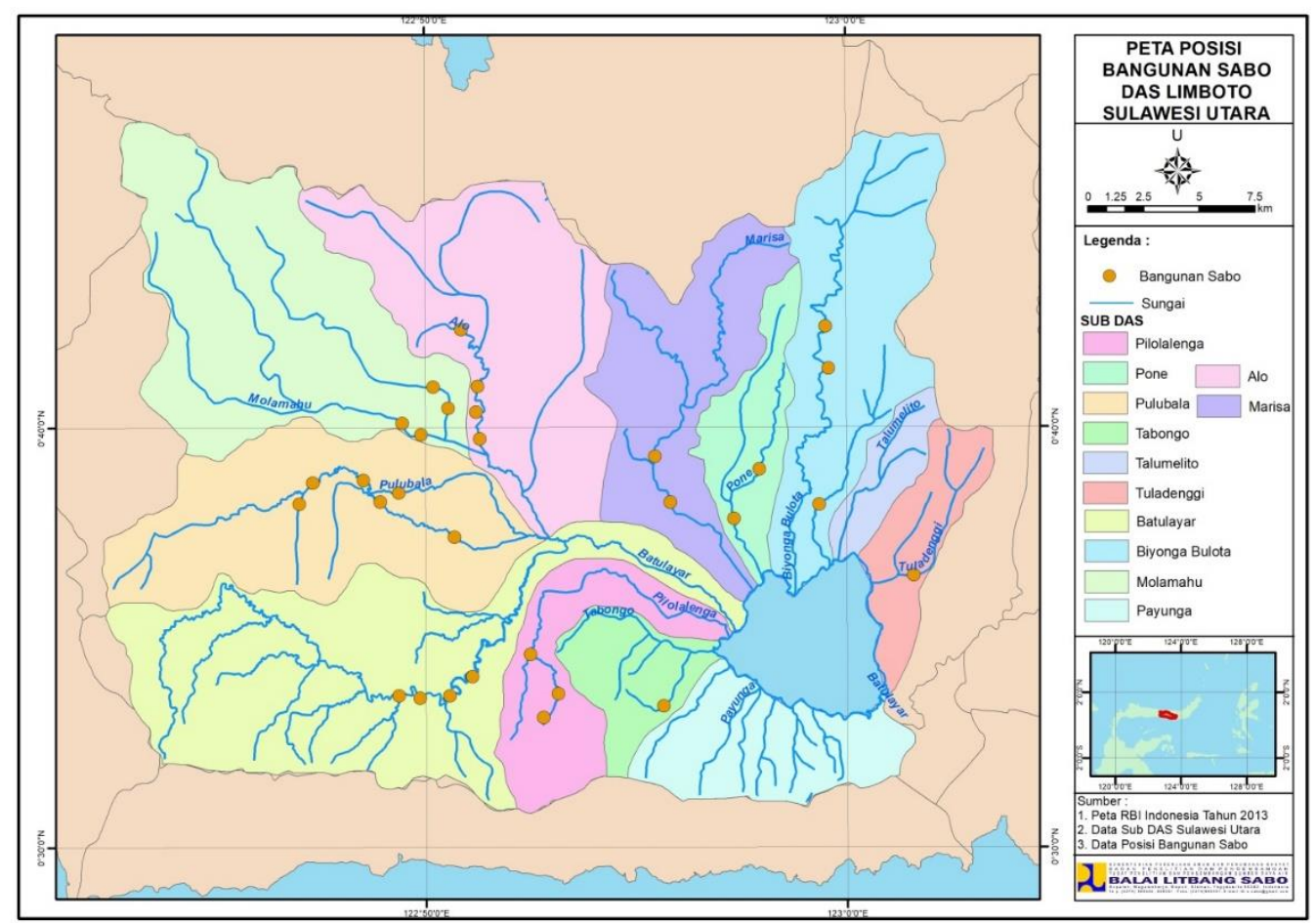

Sumber: Analisis, 2017

Gambar 3 Distribusi Sabo Dam eksisting di DAS Limboto 
Pada Gambar 3 bisa kita lihat distribusi rencana Sabo Dam yang berisi jumlah dan letaknya. Berdasar kapasitas tampungan Sabo Dam pada Sungai Batulayar, dapat kita lihat akan mampu mengendalikan volume sedimen sasaran/berlebih yang ada, sehingga tidak memerlukan adanya penambahan bangunan. Untuk sisa tampungan Sabo Dam sebesar $3.704 \mathrm{~m} 3 /$ tahun atau masih tersisa $1,87 \%$ tampungan.

Kapasitas tampungan Sabo Dam pada Biyonga bulota dan Biyonga bulota1 sudah cukup dalam mengendalikan volume sedimen sasaran/berlebih yang ada, sebesar $97,76 \%$ dan $98,49 \%$ dari kapasitas tampungan total, sehingga belum memerlukan adanya penambahan bangunan. Kapasitas tampungan Sabo Dam pada Sungai Marisa sudah cukup dalam mengendalikan volume sedimen sasaran/berlebih yang ada, sebesar 97,96\% dari kapasitas tampungan total, sehingga apabila dilihat dari sudut pandang kapasitas tampung belum memerlukan adanya penambahan bangunan.

Kapasitas tampungan Sabo Dam pada Sungai Molamahu dan Molamahu1 sangat cukup dalam mengendalikan volume sedimen sasaran/berlebih yang ada sehingga tidak memerlukan penambahan bangunan. Dalam sekali tampungan akan sisa 2,84\% dengan potensi tampungan 75.192 m3/tahun dan akan sisa tampungan di Molamahu1 sebesar 2,17 m3/tahun.

Kapasitas tampungan Sabo Dam pada Sungai Payunga sudah cukup dalam mengendalikan volume sedimen sasaran/berlebih yang ada, yaitu sebesar 99,1\% dari kapasitas tampungan total, sehingga belum memerlukan adanya penambahan bangunan. Potensi sedimen di Sungai Pilolalenga dan Pilolalenga1 terhadap kapasitas tampungan bisa kita lihat bahwa sisa tampungan apabila dibandingkan potensi sedimen yang ada hanya tersisa $819 \mathrm{~m} 3 /$ tahun serta $717 \mathrm{~m} 3 /$ tahun, sehingga tidak memerlukan adanya penambahan bangunan.

Kapasitas tampungan Sabo Dam pada Sungai Pone dan Pone1 sudah cukup dalam mengendalikan volume sedimen sasaran/berlebih yang ada, yaitu sebesar 98,34\% dan 99,22\% dari kapasitas tampungan total, sehingga belum memerlukan adanya penambahan bangunan. Kapasitas tampungan Sabo Dam pada Sungai Pulubala, Pulubala1 dan Pulubala2 sudah cukup dalam mengendalikan volume sedimen sasaran/berlebih yang ada, yaitu sebesar 97,52\%, $98,43 \%$, dan 97,97\% dari kapasitas tampungan total, sehingga belum memerlukan adanya penambahan bangunan.

Kapasitas tampungan Sabo Dam pada Sungai Tabongo dan Tabongo1 sudah cukup dalam mengendalikan volume sedimen sasaran/berlebih yang ada, yaitu sebesar 98,58\%, 98,53\% dari kapasitas tampungan total, sehingga belum memerlukan adanya penambahan bangunan. Kapasitas tampungan Sabo Dam pada Sungai Talumelito sudah cukup dalam mengendalikan volume sedimen sasaran/berlebih yang ada, yaitu sebesar 99,12\% dari kapasitas tampungan total, sehingga belum memerlukan adanya penambahan bangunan. Kapasitas tampungan Sabo Dam pada Sungai Tuladengi sudah cukup dalam mengendalikan volume sedimen sasaran/berlebih yang ada, yaitu sebesar 99,15\% dari kapasitas tampungan total, sehingga belum memerlukan adanya penambahan bangunan.

Asumsi semua hasil perhitungan dengan software dan berdasarkan tampungan Sabo Dam, secara umum potensi sedimen yang akan turun mampu ditampung Sabo Dam, sedangkan kelebihannya merupakan sedimen yang diijinkan mengalir ke hilir. Apabila potensi sedimen masih mampu ditahan oleh kemampuan rencana Sabo Dam yang sudah ada, maka belum perlu melakukan pembangunan Sabo Dam tambahan. Namun potensi dan detail desain yang telah ada perlu dilakukan review minimal 10 tahun sekali, terkait perubahan tata guna lahan yang selalu meningkat tiap tahunnya.

Keseluruhan dari analisis potensi sedimen ini sudah dikalibrasi dengan pengukuran sedimen selama musim kemarau dan musim hujan. Sedangkan verifikasi juga dilakukan dengan membandingkan hasil lapangan data sekunder BWS Sulawesi II, sehingga keakuratan data primer dan sekunder mempengaruhi hasil akhir Analisis.

\section{Peninjauan ulang implementasi perencanaan sabo di Kawasan Danau Limboto}

Tinjauan terhadap implementasi perencanaan sabo di sungai-sungai terbesar yang terdapat di hulu Danau Limboto dirangkum pada tabel 3 dan ilustrasi dituangkan pada gambar-gambar di bawah (Gambar 4 - Gambar 5). 
Tabel 4 Hasil peninjauan ulang perencanaan sabo di Kawasan Danau Limboto

\begin{tabular}{|c|c|c|c|c|}
\hline \multirow[b]{2}{*}{ Nama Sungai } & \multicolumn{4}{|c|}{ PARAMETER } \\
\hline & Tipe dan Fungsi & $\begin{array}{l}\text { Jarak Antar } \\
\text { Bangunan }\end{array}$ & $\begin{array}{c}\text { Kapasitas Tampung } \\
\text { Sabo Dam }\end{array}$ & $\begin{array}{c}\text { Zonasi Angkutan } \\
\text { Sedimen }\end{array}$ \\
\hline Alo & Cukup Sesuai & Belum Sesuai & Cukup & Cukup Sesuai \\
\hline Batulayar & Cukup Sesuai & Belum Sesuai & Cukup & Cukup Sesuai \\
\hline $\begin{array}{l}\text { Biyonga } \\
\text { bulota }\end{array}$ & Cukup Sesuai & Belum Sesuai & Cukup & Cukup Sesuai \\
\hline Molamahu & Cukup Sesuai & Belum Sesuai & Cukup & Cukup Sesuai \\
\hline Pulubala & Cukup Sesuai & Belum Sesuai & Cukup & Cukup Sesuai \\
\hline Pone & Cukup Sesuai & Belum Sesuai & Cukup & Cukup Sesuai \\
\hline Marisa & Cukup Sesuai & Belum Sesuai & Cukup & Cukup Sesuai \\
\hline Pilolalenga & Cukup Sesuai & Belum Sesuai & Cukup & Cukup Sesuai \\
\hline Talumelito & \multicolumn{4}{|c|}{ Belum ada desain/eksisting bangunan } \\
\hline Tabongo & Cukup Sesuai & Belum Sesuai & Cukup & Cukup Sesuai \\
\hline Tuladengi & Cukup Sesuai & Belum Sesuai & Cukup & Cukup Sesuai \\
\hline Payungan & \multicolumn{4}{|c|}{ Belum ada desain/eksisting bangunan } \\
\hline
\end{tabular}

Sumber: Analisis, 2017

Secara garis besar, bangunan sabo di Sungai Alo, Pilolalenga, Pulubala dan Tuladengi sudah cukup meskipun jarak antar bangunan kurang cukup dan berpotensi menyebabkan kegagalan sabo. Untuk itu, penambahan bangunan sabo untuk mengurangi jarak antar bangunan dan mengurangi laju sedimentasi disarankan. Penambahan bangunan sabo pada zona transportasi perlu dilakukan di beberapa sungai, yaitu Sungai Batulayar, Biyota Balunga, Marisa dan Tabongo, sebab pendeknya alur pada zona tersebut memungkinkan adanya peningkatan kecepatan aliran sementara material sedimen terangkut belum optimal saat memasuki zona pengendapan, yang seharusnya berkecepatan lambat dengan material yang halus untuk memudahkan pengendapan.

Di sisi lain, ada beberapa sungai yang dapat diperkuat melalui pembangunan Sabo Dam tambahan. Akan tetapi, penambahan di Sungai Molamahu, Payunga dan Pone bukan merupakan prioritas karena penempatan bangunan pada zona pengendapan sudah cukup dalam menahan laju sedimentasi. 


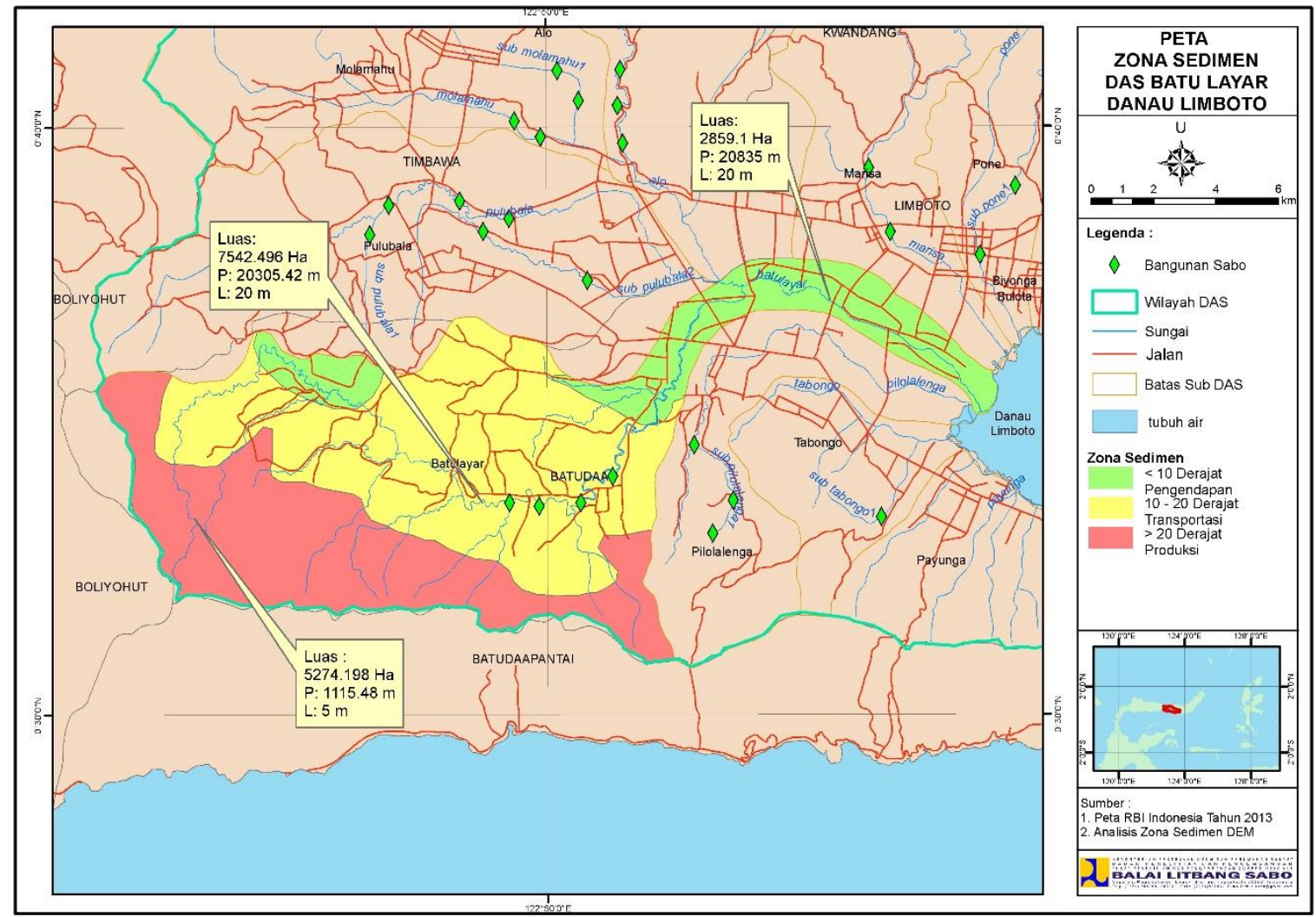

Sumber: Analisis, 2017

Gambar 4 Peta zonasi angkutan sedimen Sub-DAS Batulayar

Sungai Batulayar pada Gambar 4, memiliki zona transportasi yang lebih pendek dibandingkan dengan zona pengendapan dan keseluruhan alur sungai. Selain itu, terdapat total 4 (empat) bangunan sabo yang ada/direncanakan dan semuanya masuk dalam zona transportasi. Penempatan bangunan sabo pada zona transportasi sudah cukup sesuai, karena sebaiknya bangunan sabo tidak dibangun pada zona produksi. Selain itu, sebaiknya perlu dilakukan penambahan Sabo Dam pada zona transportasi. Pendeknya alur pada zona transportasi, dapat menyebabkan kecepatan dan jumlah material sedimen yang terangkut ketika banjir sedimen terjadi belum banyak berkurang ketika memasuki zona pengendapan. Sedimen yang terangkut pada zona pengendapan, seharusnya sudah memiliki kecepatan yang lambat dan material cenderung halus, sehingga dapat terendapkan pada alur sungai.
Sungai Alo pada Gambar 5 kiri, memiliki zona transportasi yang lebih pendek dibandingkan dengan zona pengendapan dan keseluruhan alur sungai zona produksi. Selain itu, dari 4 (empat) bangunan sabo yang ada, terdapat 2 (dua) bangunan dalam zona produksi, 1 (satu) di zona transportasi, dan 1 (satu) bangunan dalam zona pengendapan. Penempatan bangunan sabo pada zona pengendapan dan zona transportasi sudah sesuai, karena sebaiknya Sabo Dam tidak dibangun pada zona produksi. Selain itu, dengan adanya bangunan sabo pada zona transportasi, ditambah lagi dengan pendeknya alur pada zona tersebut, dapat mengurangi kecepatan dan jumlah material sedimen yang terangkut ketika banjir sedimen terjadi. Penempatan sabo pada zona produksi di Sungai Alo, bisa dikategorikan ke dalam zona transportasi pada alur sungai, karena daerah atas masuk ke dalam zona transportasi. 

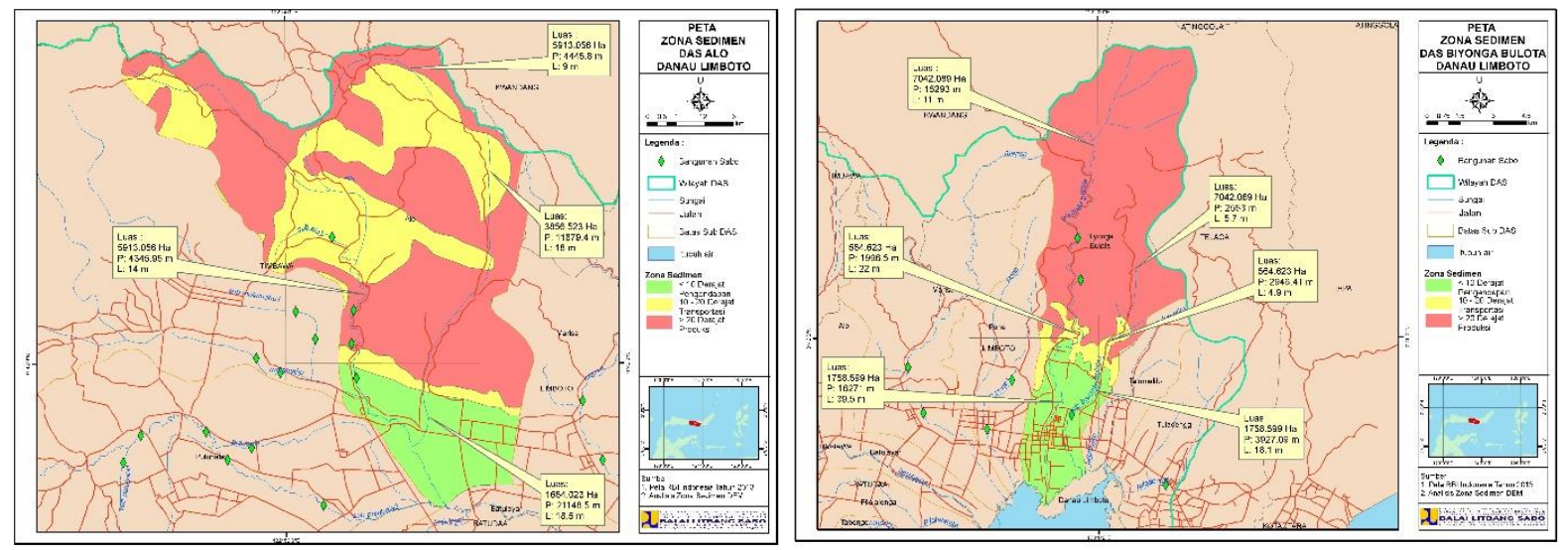

Sumber: Analisis, 2017

Gambar 5 Peta zonasi angkutan sedimen Sub-DAS Alo (kiri) dan Biyonga Bulota (kanan)

Sungai Biyonga Bulota pada Gambar 5 kanan, memiliki zona transportasi yang lebih pendek dibandingkan dengan zona pengendapan, apalagi bila dibandingkan dengan zona produksi. Terdapat 3 (tiga) bangunan sabo yang direncanakan atau eksisting menurut BWS Sulawesi II. Dua buah ada di daerah produksi serta satu buah di daerah pengendapan. Terdapat 3 (tiga) bangunan sabo yang direncanakan/eksisting di anak Sungai Biyonga Bulota1, dua buah Sabo Dam ini terletak pada zona produksi, serta satu buah Sabo Dam terletak pada zona pengendapan. Penempatan bangunan sabo pada zona pengendapan sudah cukup sesuai, karena kecepatan transportasi sedimen sudah berkurang di zona ini. Selain itu, sebaiknya perlu dilakukan penambahan bangunan sabo pada zona transportasi. Hal ini karena pendeknya alur zona transportasi, dapat menyebabkan kecepatan dan jumlah material sedimen yang terangkut ketika banjir lahar terjadi belum banyak berkurang ketika memasuki zona pengendapan.

Dari hasil peninjauan ulang, dapat diketahui bahwa sebagian besar sungai yang berada pada kawasan Danau Limboto, memerlukan penambahan bangunan Sabo Dam, minimal satu buah Sabo Dam, terutama untuk 5 (lima) sungai dengan potensi produksi sedimen terbesar yang mampu menjadi sedimentasi danau, yaitu sungai di Sub-DAS Alo, Sub-DAS Batulayar, Sub-DAS Biyonga Bulota, Sub-DAS Molamahu, serta Sub-DAS Pulubala. Hal ini dilihat dari jarak antar Sabo Dam yang masih jauh antara satu dengan lainnya (tabel 4).

Penempatan paling baik adalah pada zona transportasi, serta setelah pertemuan dua sungai atau anak sungai atau lebih. Jika ditinjau dari parameter jarak antar bangunan dan kapasitas tampungnya, jarak antar bangunan Sabo Dam masih sangat jauh antara satu dengan lainnya (tabel 3 dan tabel 5).

Berdasarkan hasil tinjauan ulang kapasitas tampungan, apabila ada tambahan satu dam di setiap sungai, maka potensi sedimentasi (dari tutupan lahan, longsoran tebing sungai, dan erosi dasar/alur sungai), mampu ditampung oleh Sabo Dam. Kondisi teknis lokasi usulan penambahan bangunan pada sungai-sungai di kawasan Danau Limboto, yang berada pada zona transportasi atau pengendapan, semua berupa area ladang, serta semak-semak untuk kondisi kiri dan kanan lokasi Sabo Dam.

Tabel 5 Hasil analisis jarak antar Sabo Dam eksisting

\begin{tabular}{l|l|l}
\hline No & Nama Sungai & Jarak $(\mathrm{km})$ \\
\hline 1 & Piyonga Bulota & 2,40 \\
\hline 2 & Marisa & 2,42 \\
\hline 3 & \multirow{2}{*}{ Alo } & 1,80 \\
\cline { 3 - 3 } & & 1,43 \\
\hline 4 & Sub-Molamahu & 2,06 \\
\hline 5 & Molamahu & 1,31 \\
\hline 6 & Sub-Pulubala2 & 4,30 \\
\hline 7 & Pulubala & 3,54 \\
\hline 8 & & 2,50 \\
\hline 9 & Batulayar & 1,73 \\
\cline { 3 - 3 } & & 2,76 \\
\cline { 3 - 3 } & & 3,02 \\
\hline
\end{tabular}

Sumber: Analisis, 2017 
Tabel 6 Usulan penambahan bangunan berdasarkan hasil peninjauan perencanaan sabo

\begin{tabular}{|c|c|c|}
\hline No & Nama Sungai & Usulan Tambahan Bangunan \\
\hline \multirow{3}{*}{1} & \multirow{3}{*}{ Alo } & 1 (satu) buah pada zona transportasi/pengendapan \\
\hline & & Asumsi 1 bangunan memiliki kapasitas tampung sebesar $118.404 \mathrm{~m}^{3}$ \\
\hline & & (tinggi/h=2 m dan lebar/w=20 m) \\
\hline \multirow{3}{*}{2} & \multirow{3}{*}{ Alo1 } & 1 (satu) buah pada zona transportasi/pengendapan \\
\hline & & Asumsi 1 bangunan memiliki kapasitas tampung sebesar $120.495 \mathrm{~m}^{3}$ \\
\hline & & (tinggi/h=1,5 m dan lebar/w=14 m) \\
\hline \multirow{3}{*}{3} & \multirow{3}{*}{ Batulayar } & 1 (satu) buah pada zona transportasi/pengendapan \\
\hline & & Asumsi 1 bangunan memiliki kapasitas tampung sebesar $197.366 \mathrm{~m}^{3}$ \\
\hline & & (tinggi/h=1,5 m dan lebar/w=35 m) \\
\hline \multirow{3}{*}{4} & \multirow{3}{*}{ Biyonga bulota } & 1 (satu) buah pada zona transportasi \\
\hline & & Asumsi 1 bangunan memiliki kapasitas tampung sebesar $125.914 \mathrm{~m}^{3}$ \\
\hline & & (tinggi/h=2 m dan lebar/w=31 m) \\
\hline \multirow{3}{*}{5} & \multirow{3}{*}{ Biyonga bulota1 } & 1 (satu) buah pada zona transportasi/pengendapan \\
\hline & & Asumsi 1 bangunan memiliki kapasitas tampung sebesar $26.291 \mathrm{~m}^{3}$ \\
\hline & & (tinggi/h=1,5 m dan lebar/w=17 m) \\
\hline \multirow{3}{*}{6} & \multirow{3}{*}{ Marisa } & 1 (satu) buah pada zona transportasi/pengendapan \\
\hline & & Asumsi 1 bangunan memiliki kapasitas tampung sebesar $58.266 \mathrm{~m}^{3}$ \\
\hline & & (tinggi/h=1,5 m dan lebar/w=11 m) \\
\hline \multirow{3}{*}{7} & \multirow{3}{*}{ Molamahu } & 1 (satu) buah pada zona transportasi \\
\hline & & Asumsi 1 bangunan memiliki kapasitas tampung sebesar $75.192 \mathrm{~m}^{3}$ \\
\hline & & (tinggi/h=2 $\mathrm{m}$ dan lebar $/ \mathrm{w}=26 \mathrm{~m}$ ) \\
\hline \multirow{3}{*}{8} & \multirow{3}{*}{ Molamahu1 } & 1 (satu) buah pada zona transportasi \\
\hline & & Asumsi 1 bangunan memiliki kapasitas tampung sebesar $40.464 \mathrm{~m}^{3}$ \\
\hline & & (tinggi/h=1,5 $\mathrm{m}$ dan lebar $/ \mathrm{w}=22 \mathrm{~m}$ ) \\
\hline \multirow{3}{*}{9} & \multirow{3}{*}{ Payunga } & minimal 1 (satu) buah pada zona transportasi \\
\hline & & Asumsi 1 bangunan memiliki kapasitas tampung sebesar $26.987 \mathrm{~m}^{3}$ \\
\hline & & (tinggi/h=2 m dan lebar/w=10 m) \\
\hline \multirow{3}{*}{10} & \multirow{3}{*}{ Pilolalenga } & 1 (satu) buah pada zona transportasi/pengendapan \\
\hline & & Asumsi 1 bangunan memiliki kapasitas tampung sebesar $33.124 \mathrm{~m}^{3}$ \\
\hline & & (tinggi/h=1,5 $\mathrm{m}$ dan lebar/w=22 m) \\
\hline \multirow{3}{*}{11} & \multirow{3}{*}{ Pilolalenga1 } & 1 (satu) buah pada zona pengendapan \\
\hline & & Asumsi 1 bangunan memiliki kapasitas tampung sebesar $22.558 \mathrm{~m}^{3}$ \\
\hline & & (tinggi/h=1,5 $\mathrm{m}$ dan lebar $/ \mathrm{w}=50 \mathrm{~m}$ ) \\
\hline \multirow{3}{*}{12} & \multirow{3}{*}{ Pone } & 1 (satu) buah pada zona transportasi/pengendapan \\
\hline & & Asumsi 1 bangunan memiliki kapasitas tampung sebesar $40.932 \mathrm{~m}^{3}$ \\
\hline & & (tinggi/h=2 m dan lebar/w=15 m) \\
\hline
\end{tabular}




\begin{tabular}{|c|c|c|}
\hline No & Nama Sungai & Usulan Tambahan Bangunan \\
\hline \multirow{3}{*}{13} & \multirow{3}{*}{ Pone1 } & 1 (satu) buah pada zona transportasi/pengendapan \\
\hline & & Asumsi 1 bangunan memiliki kapasitas tampung sebesar $27.519 \mathrm{~m}^{3}$ \\
\hline & & (tinggi/h=1,5 $\mathrm{m}$ dan lebar/w=11 m) \\
\hline \multirow{3}{*}{14} & \multirow{3}{*}{ Pulubala } & 1 (satu) buah pada zona transportasi/pengendapan \\
\hline & & Asumsi 1 bangunan memiliki kapasitas tampung sebesar $54.803 \mathrm{~m}^{3}$ \\
\hline & & (tinggi/h=2 m dan lebar/w=10 m) \\
\hline \multirow{3}{*}{15} & \multirow{3}{*}{ Pulubala1 } & 1 (satu) buah pada zona transportasi/pengendapan \\
\hline & & Asumsi 1 bangunan memiliki kapasitas tampung sebesar $18.023 \mathrm{~m}^{3}$ \\
\hline & & (tinggi/h=1,5 $\mathrm{m}$ dan lebar/w=16 $\mathrm{m}$ ) \\
\hline \multirow{3}{*}{16} & \multirow{3}{*}{ Pulubala2 } & 1 (satu) buah pada zona transportasi \\
\hline & & Asumsi 1 bangunan memiliki kapasitas tampung sebesar $31.913 \mathrm{~m}^{3}$ \\
\hline & & (tinggi/h=1,5 $\mathrm{m}$ dan lebar/w=16 m) \\
\hline \multirow{3}{*}{17} & \multirow{3}{*}{ Tabongo } & 1 (satu) buah pada zona transportasi/pengendapan \\
\hline & & Asumsi 1 bangunan memiliki kapasitas tampung sebesar $20.314 \mathrm{~m}^{3}$ \\
\hline & & (tinggi/h=1,5 $\mathrm{m}$ dan lebar/w=5 m) \\
\hline \multirow{3}{*}{18} & \multirow{3}{*}{ Tabongo1 } & 1 (satu) buah pada zona transportasi/pengendapan \\
\hline & & Asumsi 1 bangunan memiliki kapasitas tampung sebesar $11.195 \mathrm{~m}^{3}$ \\
\hline & & (tinggi/h=1,5 m dan lebar/w=9 m) \\
\hline \multirow{3}{*}{19} & \multirow{3}{*}{ Talumelito } & 1 (satu) buah pada zona transportasi/pengendapan \\
\hline & & Asumsi 1 bangunan memiliki kapasitas tampung sebesar $32.533 \mathrm{~m}^{3}$ \\
\hline & & (tinggi/h=1,5 $\mathrm{m}$ dan lebar $/ \mathrm{w}=22 \mathrm{~m}$ ) \\
\hline \multirow{3}{*}{20} & \multirow{3}{*}{ Tuladengi } & 1 (satu) buah pada zona transportasi/pengendapan \\
\hline & & Asumsi 1 bangunan memiliki kapasitas tampung sebesar $29.157 \mathrm{~m}^{3}$ \\
\hline & & (tinggi/h=1,5 m dan lebar/w=13 m) \\
\hline
\end{tabular}

Sumber: Analisis, 2017

Di sisi lain, berdasarkan hasil tinjauan kapasitas tampungan Sabo Dam di tiap lokasi, apabila sudah ditambah dengan minimal satu struktur di masing-masing sungai dengan kapasitas dan dimensi seperti yang tertera pada Tabel 6, maka potensi sedimentasi yang berasal dari tutupan lahan, longsoran tebing sungai, dan erosi dasar/alur sungai akan dapat tertampung sabo dam. Selain itu, apabila terjadi aliran debris, maka akan mampu ditampung oleh bangunan eksisting dan tambahan. Kondisi teknis lokasi bangunan tambahan usulan, di zona transportasi atau pengendapan, saat ini merupakan ladang dan semak-semak (di sekitaran Sabo Dam eksisting).

Dari hasil analisis, diperlukan adanya kegiatan pembaruan peninjauan perencanaan sabo sebelum pembangunan, karena kondisi alur sungai yang sangat dinamis, data potongan melintang serta memanjang tiap sungai yang belum lengkap. Diharapkan juga adanya kegiatan monitoring sebelum pelaksanaan pembangunan Sabo Dam, untuk melihat kesesuaian penambahan bangunan berdasarkan hasil peninjauan ulang Balai Sabo. Selain itu juga diperlukan adanya studi lebih lanjut terkait perencanaan sabo pada Sungai Alo, Batulayar, dan Biyonga bulota, dengan pertimbangan bahwa ketiga sungai tersebut memiliki potensi erosi, serta sedimentasi terbesar yang bisa masuk ke Danau Limboto.

\section{KESIMPULAN}

Dari hasil peninjauan perencanaan sabo yang telah dilakukan oleh Balai Litbang Sabo, serta fakta lapangan, dapat diambil kesimpulan bahwa Secara umum perencanaan sabo oleh Balai Wilayah Sungai Sulawesi II cukup menanggulangi potensi erosi dan sedimentasi di Kawasan Danau Limboto. Hal ini 
menepis hipotesis awal kajian, yaitu jumlah Sabo Dam kurang dan letak bangunan belum sesuai dengan kaidah perencanaan sabo. Hasil peninjauan ulang Sabo Dam, berdasarkan parameter kapasitas tampung, penambahan bangunan di sungai hulu danau tidak diperlukan. Di sisi lain, berdasarkan jarak antar bangunan Sabo Dam, masing-masing sungai memerlukan minimum 1 bangunan tambahan. Usulan penambahan kapasitas tampung mencapai 1.111.537 $\mathrm{m}^{3}$. Sub-DAS Batulayar memiliki kapasitas tampung terbesar $193.662 \mathrm{~m}^{3}$ per tahun, sedangkan terkecil yaitu Tabongo1 memiliki Sabo Dam dengan kapasitas mencapai $11.031 \mathrm{~m}^{3}$ per tahun. Kedepannya perlu adanya peninjauan terjadwal sebelum pembangunan, agar sesuai dengan kondisi terkini di lapangan, sehingga mampu menanggulangi potensi erosi dan sedimentasi kawasan Danau Limboto.

\section{UCAPAN TERIMA KASIH}

Penulis mengucapkan terima kasih kepada Kapuslitbang SDA, kepala Balai Litbang Sabo beserta strukturalnya, kepala Balai BHGK beserta strukturalnya, BWS Sulawesi II Gorontalo, serta semua pihak yang telah mendukung sehingga makalah ini dapat tersusun yg tidak dapat kami sebutkan satu per satu.

\section{DAFTAR PUSTAKA}

Akibu, R. S. (2017). Implementasi Kebijakan Pengelolaan Danau Limboto. DIALEKTIKA : Jurnal Ekonomi Dan Ilmu Sosial, 2(1), 178-188. doi:10.36636/dialektika.v2i1.241

Alatorre, L., Beguería, S., \& García-Ruiz, J. (2010). Regional scale modeling of hillslope sediment delivery: A case study in the Barasona Reservoir watershed (Spain) using WaTEM/SEDEM. Journal of Hydrology, 391(1-2), 109-123.

doi:10.1016/j.jhydrol.2010.07.010

Badan Standardisasi Nasional. (2015). SNI 2851-2015 TENTANG DESAIN BANGUNAN PENAHAN SEDIMEN [PDF]. Jakarta: Badan Standardisasi Nasional.

Hassan, C. (2018). Sabo Plan (For Measure Against Lahar/Sediment Flows) [PPT]. Sleman: Universitas Gadjah Mada.
Kementerian Lingkungan Hidup. (2014). Gerakan Penyelamatan Danau (GERMADAN) Limboto [PDF]. Jakarta: Kementerian Lingkungan Hidup.

Kementerian Pekerjaan Umum dan Perumahan Rakyat. (2017). Kementerian PUPR Revitalisasi Danau Limboto. Retrieved February 26, 2017, from https://www.pu.go.id/berita/view/10818/kemen terian-pupr-revitalisasi-danau-limboto

Kementerian Pekerjaan Umum dan Perumahan Rakyat. (2019). Revitalisasi Danau Limboto Masuk Tahap Lanjutan 6. Retrieved June 26, 2019, from http://sda.pu.go.id/pages/posts/RevitalisasiDanau-Limboto-Masuk-Tahap-Lanjutan-6

Notebaert, B., Vaes, B., Verstraeten, G., \& Govers, G. (2006). PDF [Manual]. Flanders: KU Leuven.

Polontalo, S. (2010, February 01). Konservasi Danau Limboto 1. Pendahuluan. Retrieved June 26, 2019, from https://menyelamatkandanaulimboto.wordpress. com/profil-danau-limboto/1-pendahuluan/

Siswo, B. (2010, February 03). Limboto Danau Terdangkal di Indonesia. Retrieved June 26, 2017, from https://menyelamatkandanaulimboto.wordpress. com/artikel-danau-limboto/b-siswo/

Takahashi, T. (2007). Debris flow: Mechanics, prediction, and countermeasures. London, United Kingdom: Taylor and Francis.

Udiana, I. (2011). MODEL PERENCANAAN BANGUNAN SABO UNTUK PENGENDALIAN ALIRAN DEBRIS (DEBRIS FLOW). Jurnal Teknik Sipil Universitas Kristen Petra, 1(1), 28-40. Retrieved June 26, 2019, from http://puslit2.petra.ac.id/ejournal/index.php/jur nal-teknik-sipil/article/view/18579

Van Rompaey, A., Bazzoffi, P., Jones, R. J., \& Montanarella, L. (2005). Modeling sediment yields in Italian catchments. Geomorphology, 65 (1-2), 157-169. doi:10.1016/j.geomorph.2004.08.006 